\title{
Voltammetric behavior of a Chemically Modified Carbon Paste Electrode with Cadmium Nitroprusside Prepared in Different Water to Formamide Ratios
}

Tamires Rocha Souza ${ }^{1}$, Acelino Cardoso de Sán, Fernanda dos Santos Franco ${ }^{1}$, Priscila Fernanda Pereira Barbosa ${ }^{1}$, Rômulo Davi Albuquerque Andrade ${ }^{3}$,Fabíla Medeiros da Costa ${ }^{1}$, Kamilla Alves Carvalho ${ }^{1}$, Denys Ribeiro de Oliveira ${ }^{1}$, Loanda Raquel Cumba ${ }^{4}$, Leonardo Lataro Paim ${ }^{5}$, Eduardo Guimarães Vieira ${ }^{6}$ Devaney Ribeiro do Carmo ${ }^{1, *}$

${ }^{1}$ São Paulo State University (Unesp), School of Engineering, Department of Physics and Chemistry, Campus of Ilha Solteira, Brazil.

${ }^{2}$ São Carlos Institute of Physics, University of São Paulo, CP 369, São Carlos, Brazil.

${ }^{3}$ Institute of Education, Science and Technology of Goiás, Campus of Valparaíso, Brazil.

${ }^{4}$ School of Chemical Sciences, Dublin City University, Dublin 9, Ireland.

${ }^{5}$ São Paulo State University (Unesp), Energy Engineering, Campus of Rosana, Brazil

${ }^{6}$ Department of Fundamental Chemistry, Institute of Chemistry, University of São Paulo, São Paulo, Brazil

*E-mail: devaneydocarmo@ hotmail.com

doi: $10.20964 / 2020.01 .54$

Received: 18 August 2019 / Accepted: 15 October 2019 / Published: 30 November 2019

This paper describes a voltammetric study of cadmium nitroprusside synthesized from different compositions of water/formamide in your reaction of $\mathrm{Cd}^{2+}$ with $\left[\mathrm{Fe}^{\mathrm{III}}(\mathrm{CN})_{5} \mathrm{NO}\right]^{2-}(\mathrm{CdNP})$. After infrared and transmission electron microscopy characterization, the CdNP was incorporated into a carbon paste electrode and a systematic voltammetric study was performed for four systems (CdNP-1, CdNP-2, CdNP-3 and CdNP-4). The spectroscopic studies reveals that all preparations was conducted with success. The cyclic voltammogram of all CdNP particles obtained from a carbon paste electrode modified $(10 \% \mathrm{~m} / \mathrm{m})$ exhibited a redox couple with formal potential $\left(\mathrm{E}^{\theta^{\prime}}\right)=0.63 \pm 0.02 \mathrm{~V}(10 \%(\mathrm{~m} / \mathrm{m})$; $\left.\mathrm{v}=20 \mathrm{mV} \mathrm{s}^{-1} ; \mathrm{KNO}_{3} 1.0 \mathrm{M}\right)$ ) attributed to the redox process $\left[\mathrm{Fe}^{\mathrm{II}}(\mathrm{CN})_{5} \mathrm{NO}\right] /\left[\mathrm{Fe}^{\mathrm{III}}(\mathrm{CN})_{5} \mathrm{NO}\right]$ in the presence of $\mathrm{Cd}^{2+}$.

Keywords: Cadmium nitroprusside, voltammetry, formamide, eletro-oxidation, isoniazid

\section{$\underline{\text { FULL TEXT }}$}

(C) 2020 The Authors. Published by ESG (www.electrochemsci.org). This article is an open access article distributed under the terms and conditions of the Creative Commons Attribution license (http://creativecommons.org/licenses/by/4.0/). 